\title{
Konstruksi Berpikir Hakim Dalam Menerapkan Asas Lex Specialis Systematisch Terhadap Penegakan Hukum Tindak Pidana Korupsi
}

\author{
Dara Jayanita Haq \\ Universitas Riau, Indonesia, darajayanita@gmail.com
}

\begin{abstract}
Establishment of special laws that are outside the sectoral specific Criminal Code. Each rules according to the sector. This condition has the potential of one another. To determine which Special Law is applied, then the principle of lex specialis systematisch or systematic specificity applies. in the decision of the issued verdict, the decision of the decision that did not include the principle of lex specialis systematisch was not included. Where the principle of lex specialis systematisch must be applied to the verdict. How to determine the difference in assessment in applying the principle of lex specialis systematisch is because of a different understanding of State Financial Losses by law enforcers relating to their attitudes and judgments.
\end{abstract}

Keywords: Principle of Lex Specialis Systematisch - Law Enforcement - Corruption Crime.

\begin{abstract}
ABSTRAK
Pembentukan undang-undang khusus yang berada di luar KUHP bersifat sektoral. Masing-masing membentuk aturan sesuai sektornya. Kondisi ini memiliki potensi singgungan satu dengan lainnya. Untuk menentukan Undang-Undang Khusus mana yang diberlakukan, maka berlaku asas lex specialis systematisch atau kekhususan yang sistematis. Pada keempat putusan yang diteliti tidak terdapat satupun putusan yang menerapkan asas lex specialis systematisch. Dimana seharusnya asas lex specialis systematisch itu harus diterapkan terhadap keempat putusan yang diteliti dalam penelitian ini. Penyebab terjadinya perbedaan putusan hakim dalam menerapkan asas lex specialis systematisch adalah karena pemahaman yang bervariasi terhadap Kerugian keuangan Negara oleh para penegak hukum yang memiliki dampak terhadap sikap dan pendapat mereka.
\end{abstract}

Kata Kunci: Asas Lex Specialis Systematisch - Penegakan Hukum - Tindak Pidana Korupsi 
PENDAHULUAN

\section{A. Latar Belakang Masalah}

Kegiatan kehidupan manusia sangatlah luas sehingga tidaklah mungkin dicakupkan kedalam satu peraturan perundangundangan dengan tuntas dan jelas. Peraturan hukum yang ada bersifat (das sollen) sedangkan peristiwa hukum itu bersifat kongkret (das sein). Keadaan hukum yang tidak ada atau tidak jelas atau kabur dan amanah Pasal 10 ayat (1) Undang-Undang Nomor 48 Tahun 2009 tentang Kekuasaan Kehakiman yang menyatakan bahwa pengadilan tidak boleh menolak untuk memeriksa, mengadili, dan memutus suatu perkara yang diajukan kepadanya, dengan dalih hukumnya tidak ada atau tidak jelas (rechtsweigering). Adanya asas yang menganggap hakim

mengetahui semua hukum (ius curia novit) menjadi beberapa alasan pentingnya dilakukan penemuan hukum.

\begin{tabular}{|c|}
\hline Ketentuan \\
\hline dimaknai dengan \\
\hline "perundang-undangan pidana \\
\hline khusus" dan ketentuan umum \\
\hline dimaknai dengan kriteria \\
\hline "perundang-undangan pidana \\
\hline umum". Tidak dimaknai \\
\hline sebagai hukum yang khusus \\
\hline tetapi undang-undangnya \\
\hline tersendiri (afzonderlijk) di luar \\
\hline Selanjutanya \\
\hline dikatakan bahwa perundang- \\
\hline undangan pidana khusus ialah \\
\hline semua perundang-undangan di \\
\hline luar KUHP yang mengandung \\
\hline ketentuan pidana, sedangkan \\
\hline perundang-undangan pidana \\
\hline umum ialah KUHP dan semua \\
\hline perundang-undangan \\
\hline
\end{tabular}
Ketentuan khusus 政 
mengubah dan menambah $\mathrm{KUHP}^{1}$.

Pembentukan undangundang khusus yang berada di luar KUHP bersifat sektoral. Masing-masing membentuk aturan sesuai sektornya. Kondisi ini memiliki potensi singgungan satu dengan lainnya. Kemungkinan adanya satu perbuatan pidana pada suatu undang-undang khusus terdapat atau diatur juga dalam ketentuan pidana pada undang-undang khusus lainnya. Satu tindak pidana yang diatur dalam ketentuan umum juga diatur pada ketentuan khusus, dengan asas lex specialis derogat legi generali dapat segera ditetapkan ketentuan yang khusus lebih diutamakan daripada ketentuan umum.

1 Andi Hamzah. 1991. Perkembangan Hukum Pidana Khusus, Jakarta: Rineka Cipta, hlm. 5 .
Pemilihan yang lebih kritis akan terjadi terhadap ketentuan yang harus digunakan adalah pada satu perbuatan yang diatur lebih dari satu ketentuan khusus.

Menurut Prof.

Indriyanto Seno Adji, S.H., M.H., untuk menentukan Undang-Undang Khusus mana yang diberlakukan, maka berlaku asas lex specialis systematisch atau kekhususan yang sistematis, artinya ketentuan pidana yang bersifat khusus apabila pembentuk undang-undang memang bermaksud untuk memberlakukan ketentuan pidana tersebut sebagai suatu ketentuan pidana yang bersifat khusus atau ia akan bersifat khusu dari khusus yang telah ada. Misalnya, subyek personal, obyek dugaan perbuatan yang dilanggar, alat bukti yang diperoleh, 
lingkungan dan area delicti berada dalam konteksi perbankan, maka UndangUndang Perbankan adalah yang diberlakukan, meskipun Undang-Undang Khusus lainnya (seperti UndangUndang Tindak Pidana Korupsi memiliki unsur delik yang dapat mencakupnya) adalah akseptabilitasnya ${ }^{2}$.

Persoalan asas lex specialis systematisch walau bagaimana pun juga terdapat di dalam beberapa dakwaan yang diterapkan terhadap terdakwa untuk selanjutnya diperiksa di persidangan.

Pada perkara nomor 03/Pid.Sus.TPK/2015/ PN.Mdn dengan terdakwa dr. Viktor, M.Kes selaku Pengguna Anggaran/Barang pada Dinas Kesehatan Kabupaten Toba Samosir

${ }^{2}$ Indriyanto Seno Adji. 2009. Korupsi dan Penegakan Hukum, Jakarta: Diadit Media, 2009, hlm. 171. didakwa sebagai yang

melakukan, menyuruh melakukan atau turut serta melakukan perbuatan yang secara melawan hukum melakukan perbuatan memperkaya diri sendiri atau orang lain atau suatu korporasi yang dapat merugikan keuangan Negara atau perekonomian Negara secara berturut-turut dari bulan Juli 2010 sampai dengan bulan April 2011 sehingga harus dipandang sebagai suatu perbuatan berlanjut. Perbuatan terdakwa telah melanggar ketentuan sebagaimana diatur dan diancam pidana dalam Pasal 2 ayat (1) jo Pasal 18 Undang-Undang Nomor 31 Tahun 1999 tentang Pemberantasan Tindak Pidana Korupsi sebagaimana yang telah diubah menjadi UndangUndang Nomor 20 Tahun 2001 tentang Perubahan atas 
Undang-Undang Nomor 31

Tahun 1999 tentang

Pemberantasan Tindak Pidana

Korupsi jo Pasal 55 ayat (1)

ke-1 jo Pasal 64 ayat (1)

KUHP. Sementara itu

perbuatan terdakwa juga ditur

dalam Pasal 39 ayat (1) huruf i

jo Pasal 43 ayat (1) Undang-

Undang ketentuan Umum dan

Tata Cara Perpajakan (KUP)

yang juga merupakan Undang-

Undang Khusus seperti halnya

dengan Undang-Undang

Tindak Pidana Korupsi.

Pada perkara nomor 57/Pid.Sus/TPK/2016/PN.Sby.

Fitriyah Mayasari als. Maya bersama-sama dengan terdakwa lainnya diancam pidana dalam Pasal 2 ayat (1) jo Pasal 18 Undang-Undang Nomor 31 Tahun 1999 tentang Pemberantasan Tindak Pidana Korupsi sebagaimana telah diubah dengan UndangUndang Nomor 20 Tahun
2001Tentang Perubahan atas Undang-Undang Nomor 31 Tahun 1999 Tentang Pemberantasan Tindak Pidana Korupsi jo. Pasal 55 ayat (1) ke-1 KUHP. Perbuatan tersebut juga diatur secara khusus pada Pasal 49 ayat (1) dan ayat (2) Undang-Undang Perbankan.

Pada Perkara nomor 886/Pid.Sus.K/2015/PN.Mdn. dengan terdakwa Dagner Manurung selaku Bendahara Pengeluaran pada Dinas Kesehatan Kabupaten Toba Samosir didakwa sebagai yang melakukan, menyuruh melakukan atau turut serta melakukan perbuatan dengan tujuan untuk menguntungkan diri sendiri atau orang lain atau suatu korporasi menyalahgunakan

kewenangan, kesempatan atau sarana yang ada padanya karena jabatan atau kedudukan 
yang dapat merugikan keuangan Negara secara berturut-turut dari bulan Juli 2010 sampai dengan bulan April 2011 sehingga harus dipandang sebagai suatu perbuatan berlanjut. Perbuatan terdakwa telah melanggar ketentuan sebagaimana diatur dan diancam pidana dalam Pasal 3 ayat (1) jo Pasal 18 Undang-Undang Nomor 31 Tahun 1999 tentang Pemberantasan Tindak Pidana Korupsi sebagaimana yang telah diubah menjadi UndangUndang Nomor 20 Tahun 2001 tentang Perubahan atas Undang-Undang Nomor 31 Tahun 1999 tentang Pemberantasan Tindak Pidana Korupsi jo Pasal 55 ayat (1) ke-1 jo Pasal 64 ayat (1) KUHP. Sementara itu perbuatan terdakwa juga ditur dalam Pasal 39 ayat (1) huruf i jo. Pasal 43 ayat (1) Undang- undang ketentuan Umum dan tata Cara Perpajakan (KUP) yang juga merupakan UndangUndang Khusus seperti halnya dengan Undang-Undang Tindak Pidana Korupsi.

Demikian juga pada perkara nomor 02/Pid.SusTPK/2015/PN.Mdn. Di Kabupaten Deli Serdang Provinsi Sumatera Utara pada Dinas Pengelolaan Keuangan Daerah Kabupaten Deli Serdang terjadi tindak pidana yang dilakukan oleh seorang Pegawai Negeri Sipil pada seksi penagihan bidang pendapatan Dinas Pengelolaan Keuangan Daerah Kabupaten Deli Serdang yang bertugas sebagai pemungut pajak. Pajak yang telah dipungut tersebut seharusnya disetorkan kepada kas negara, ternyata oleh oknum tersebut tidak disetorkan kepada kas negara. Terdakwa di dakwa dengan 
Undang-Undang Tipikor yang juga perbutan terdakwa juga memenuhi kriteria yang terdapat pada Pasal 39 ayat (1) huruf i Undang-Undang Ketentuan Umum dan Tata Cara Perpajakan (KUP).

B. Perumusan Masalah

Rumusan masalah dalam penelitian ini ialah:

1. Bagaimanakah konstruksi berpikir hakim dalam menerapkan asas lex specialis systematisch terhadap penegakan hukum tindak pidana korupsi?

2. Mengapa terjadi perbedaan putusan hakim dalam menerapkan asas lex specialis systematisch terhadap penegakan hukum tindak pidana korupsi?

\section{Metode Penelitian}

Jenis penelitian atau pendekatan masalah yang akan digunakan dalam penelitian ini bersifat yuridis normatif, yaitu penelitian yang dilakukan dengan cara meneliti bahan hukum sekunder atau penelitian berdasarkan aturanaturan baku yang telah dibukukan yang disebut juga dengan penelitian kepustakaan. ${ }^{3}$

Tipe penelitian hukum normatif ini meliputi asas-asas hukum dan sinkronisasi hukum. Yaitu menganalisa penggunaan asas lex specialis systematich dalam satu tindak pidana yang melanggar dua ketentuan tindak pidana khusus. Dalam penelitian hukum normatif ini penulis melakukan penelitian terhadap asas-asas hukum yang bertitik tolak dari bidang-bidang tata hukum tertentu, dengan cara mengadakan identifikasi terlebih dahulu terhadap kaidah-kaidah hukum yang

\footnotetext{
${ }^{3}$ Soerjono Soekanto dan Sri Mamudji. 2004. Penelitian Hukum Normatif, Jakarta: PT. Raja Grafindo Persada, hlm 13.
} 
telah dirumuskan di dalam perundang-undangan tertentu ${ }^{4}$.

Dilihat dari sifatnya, penelitian ini bersifat deskriptif yang bertujuan menggambarkan secara tepat sifat-sifat suatu individu, keadaan, gejala atau kelompok tertentu, atau untuk menentukan penyebaran suatu gejala, atau untuk menentukan ada tidaknya hubungan antara suatu gejala dengan gejala lain dalam masyarakat. ${ }^{5}$

Teknik pengumpulan data dilakukan dengan cara penelitian kepustakaan (Library Research), yaitu penelitian yang dilakukan dengan cara meneliti bahan pustaka untuk memperoleh data sekunder berupa bukubuku baik koleksi pribadi maupun dari perpustakaan,

${ }^{4}$ Ibid. hlm. 15

5 Amirudin dan Zainal Asikin. 2010. Pengantar Metode Penelitian Hukum, Jakarta: Rajawali Pers, hlm. 25 artikel-artikel baik yang diambil dari media cetak maupun media elektronik, dokumen-dokumen pemerintah, termasuk peraturan perundangundangan yang berhubungan dengan permasalahan yang diteliti.

Dalam penelitian hukum normatif data dapat dianalisa secara kualitatif ataupun kuantitatif. ${ }^{6}$ Dalam penelitian ini, setelah data yang diperlukan terkumpul, maka akan diolah, disusun, dan dianalisa secara kualitatif. Pengelolaan data secara kualitatif merupakan tata cara penelitian yang menekankan analisanya pada dinamika hubungan antara fenomena yang diamati dengan menggunakan logika ilmiah, yang mana datanya tidak

\footnotetext{
${ }^{6}$ Soerjono Soekanto dan Sri Mamudji, Op.Cit, hlm.11.
} 
dianalisis

dengan

menggunakan statistik atau matematika atau berbentuk angka, ataupun yang sejenisnya, tetapi data yang telah diperoleh tersebut diuraikan secara deskriptif. $^{7}$

HASIL DAN PEMBAHASAN

A. Konstruksi Berpikir Hakim dalam Menerapkan Asas Lex Specialis Systematisch Terhadap Penegakan

Hukum Tindak Pidana Korupsi

$\begin{array}{rrr} & \text { Perbuatan } & \text { terdakwa } \\ \text { pada } & \text { putusan Nomor }\end{array}$ 03/Pid.Sus.TPK/2015/PN.Md

n, Putusan Nomor 886/Pid.Sus.K/2015/PN.Mdn, dan putusan Nomor 02/Pid.Sus-

TPK/2015/PN.Mdn adalah perbuatan yang tidak

\footnotetext{
${ }^{7}$ Bambang Waluyo. 2002. Penelitian Hukum Dalam Praktek, Jakarta: SInar Garfika, hlm. 77.
}

menyetorkan pajak yang telah dipotong/pungut. Ketiga putusan ini diperiksa dan putus dengan Undang-Undang Nomor 31 Tahun 1999 sebagaimana telah diubah menjadi Undang-Undang Nomor 20 Tahun 2001 tentang Perubahan atas UndangUndang Nomor 31 Tahun 1999 Tentang Pemberantasan Tindak Pidana Korupsi.

Sedangkan pada putusan Nomor 1407/Pid.Sus/2015/PN. PLG perbuatan yang sama seperti perbuatan yang dilakukan terdakwa pada ketiga putusan diatas, diperiksa dan diputus dengan Undang-Undang Nomor 28 Tahun 2007 tentang Ketentuan Umum dan Tata Cara Perpajakan Pasal 39 ayat (1) huruf i jo Pasal 43 ayat (1). Seharusnya ketiga putusan diatas juga diputus dengan menggunakan Undang- 
Undang Nomor 28 Tahun 2007 tentang Ketentuan Umum dan Tata Cara Perpajakan Pasal 39 ayat (1) huruf i jo Pasal 43 ayat (1), karena Undang-Undang Nomor 28 Tahun 2007 tentang Ketentuan Umum dan Tata Cara Perpajakan merupakan ketentuan hukum yang lebih khusus (lex specialis systematisch) dari pada Undang-Undang Nomor 31 Tahun 1999 sebagaimana telah diubah menjadi UndangUndang Nomor 20 Tahun 2001 tentang Perubahan atas Undang-Undang Nomor 31 Tahun 1999 Tentang Pemberantasan Tindak Pidana Korupsi. Hal ini dikuatkan dengan tidak adanya penegasan di dalam UndangUndang Nomor 28 Tahun 2007 tentang Ketentuan Umum dan Tata Cara Perpajakan bahwa perbuatan tersebut adalah tindak pidana korupsi.

Berkaitan dengan Pasal 14 Undang-Undang Nomor 31 Tahun 1999 sebagaimana telah diubah menjadi UndangUndang Nomor 20 Tahun 2001 tentang Perubahan atas Undang-Undang Nomor 31 Tahun $1999 \quad$ Tentang Pemberantasan Tindak Pidana Korupsi sehingga UndangUndang Nomor 28 Tahun 2007 tentang Ketentuan Umum dan Tata Cara Perpajakan lah yang harus diterapkan sebagai undangundang khusus yang lebih khusus (lex specialis systematisch).

Tindak pidana yang dilakukan oleh para terdakwa di dalam putusan Nomor 57/Pid.Sus/TPK/2016/PN.Sby adalah melakukan manipulasi analisa kredit, perkara ini diperiksa dan diputus dengan 
Undang-Undang Nomor 31

Tahun 1999 sebagaimana telah

diubah menjadi Undang-

Undang Nomor 20 Tahun

2001 tentang Perubahan atas

Undang-Undang Nomor 31

Tahun $1999 \quad$ Tentang

Pemberantasan Tindak Pidana

Korupsi. Sedangkan pada

putusan Nomor 1937

K/Pid.Sus/2015 perbuatan

yang sama dengan para

terdakwa pada putusan

Nomor

57/Pid.Sus/TPK/2016/PN.Sby

diperiksa dan diputus dengan

Undang-Undang Nomor 10

Tahun $1998 \quad$ Tentang

Perubahan Atas Undang-

Undang Nomor 7 Tahun 1992

Tentang Perbankan.

Seharusnya putusan

Nomor

57/Pid.Sus/TPK/2016/PN.Sby

juga diputus dengan Undang-

Undang Nomor 10 Tahun

1998 Tentang Perubahan Atas
Undang-Undang Nomor 7

Tahun 1992 Tentang

Perbankan, karena Undang-

Undang Nomor 10 Tahun

1998 Tentang Perubahan Atas

Undang-Undang Nomor 7

Tahun 1992 Tentang

Perbankan merupakan

ketentuan hukum yang lebih khusus (lex specialis

systematisch) dari pada Undang-Undang Nomor 31

Tahun 1999 sebagaimana telah diubah menjadi UndangUndang Nomor 20 Tahun 2001 tentang Perubahan atas Undang-Undang Nomor 31 Tahun $1999 \quad$ Tentang Pemberantasan Tindak Pidana Korupsi. Hal ini dikuatkan dengan tidak adanya penegasan di dalam UndangUndang Nomor 10 Tahun 1998 Tentang Perubahan Atas Undang-Undang Nomor 7 Tahun 1992 Tentang Perbankan bahwa perbuatan 
tersebut adalah tindak pidana korupsi. Berkaitan dengan Pasal 14 Undang-Undang Nomor 31 Tahun 1999 sebagaimana telah diubah menjadi Undang-Undang Nomor 20 Tahun 2001 tentang Perubahan atas UndangUndang Nomor 31 Tahun 1999 Tentang Pemberantasan Tindak Pidana Korupsi sehingga Undang-Undang Nomor 10 Tahun 1998 Tentang Perubahan Atas Undang-Undang Nomor 7 Tahun 1992 Tentang Perbankan lah yang harus diterapkan sebagai undangundang khusus yang lebih khusus (lex specialis systematisch).

\section{B. Sebab}

Terjadinya

Perbedaan Putusan Hakim

dalam Menerapkan Asas

Lex Specialis Systematisch
Terhadap

Penegakan

Hukum Tindak Pidana

Faktor-faktor

penyebab terjadinya perbedaan putusan hakim dalam menerapkan asas lex specialis systematisch terhadap penegakan hukum tindak pidana korupsi adalah:

1. Penafsiran Hakim Terhadap Kerugian Keuangan Negara

Pemahaman yang bervariasi terhadap Kerugian keuangan Negara oleh para penegak hukum memiliki dampak terhadap sikap dan pendapat mereka. Adanya pemahaman bahwa setiap Kerugian keuangan negara adalah perbuatan korupsi akan mengakibatkan tidak adanya pertimbangan penilaian apakah ada 
ketentuan lain yang lebih

khusus mengaturnya.

Seperti

pelanggaran prudential

principles perbankan yang

juga dapat mengakibatkan

kerugian keuangan negara

tidaklah dapat diartikan

sebagai perbuatan

koruptif, karena

berdasarkan pendekatan

akademis doktrinal melalui

asas lex specialis

systematisch atau

kekhususan yang

sistematis, pelanggaran

terhadap prinsip kehati-

hatian adalah menjadi area

tindak pidana perbankan,

bukan tindak pidana

korupsi. Begitu pun

dengan pelanggaran dalam

bidang perpajakan yang

juga tidak bisa diartikan

sebagai perbuatan

koruptif, karena tindak

pidana di bidang perpajakan bukanlah

tindak pidana korupsi.

Ini semua harus

menjadi landasan legalitas

untuk menghindari adanya

pelanggaran terhadap

concursus. Semua

perbuatan yang

menyimpangi aturan

tentunya diartikan sebagai

perbuatan yang melawan

hukum, tetapi tidak semua

perbuatan yang melawan

hukum dapat diartikan

sebagai perbuatan

koruptif. Asas lex specialis

systematisch atau

kekhususan yang

sistematis merupakan

sarana untuk mencegah

dan membatasi serta

meluruskan kembali arah

asas "perbuatan melawan

hukum" dan

"menyalahgunakan

wewenang" dalam tindak

pidana korupsi agar tidak 
bermakna "all embracing

act dan all purpose act".

Untuk menghindari

kekeliruan

dalam

pemahaman asas lex

specialis systematisch

sebagai doktrin akademis

yang belum tentu

dipahami oleh masyarakat

hukum, khususnya dalam

keterikatan antara

perundangan admibistrasi

yang bersanksi pidana

(administrative penal law)

dengan hukum pidana

(korupsi), maka

pembentuk undang-

undang (khususnya Prof.

Dr. Muladi, S.H., yang

pada saat itu sebagai

menteri kehakiman

Republik Indonesia)

memberikan pemahaman

eksplisitas melalui Pasal

14 Undang-undang Nomor

31 Tahun 1999 tentang
Pemberantasan Tindak

Pidana Korupsi.

Mengingat telah ada asas lex specialis systematisch sebagai pengakuan akademis tersebut, pendapat doktrin telah diformulasikan melalui norma legislasi untuk memberikan batasan-batasanmya melalui Pasal 14 UndangUndang Nomor 31 Tahun 1999 tentang Pemberantasan Tindak Pidana Korupsi yang berbunyi:

"Setiap Orang yang melanggar ketentuan undang-undang yang secara tegas menyatakan bahwa pelanggaran terhadap ketentuan undang-undang tersebut sebagai tindak pidana korupsi berlaku ketentuan yang diatur dalam undangundang ini”.

Jadi makna yang terkandung dalam 


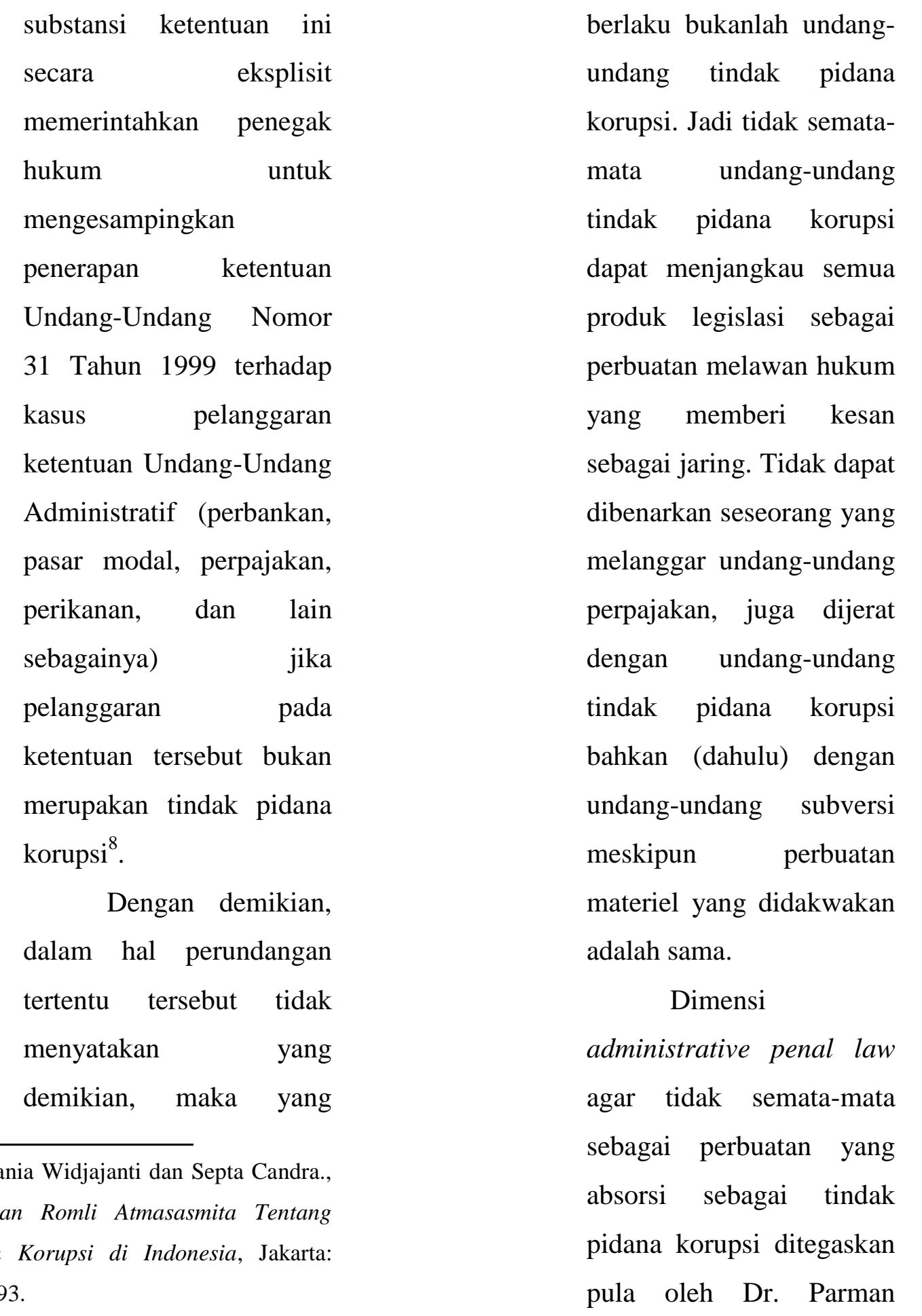


Soeparman, S.H., M.H.

(Ketua Muda Bidang

Tindak Pidana Mahkamah Agung Republik Indonesia) dalam makalahnya yang berjudul "Dimensi administrative penal law Sebagai Tindak Pidana Korupsi”, dan Hasil Rakernas Mahkamah Agung Republik Indonesia dengan Jajaran Pengadilan Empat Lingkungan Peradilan Seluruh Indonesia di Makassar tanggal 2-6 September 2007.

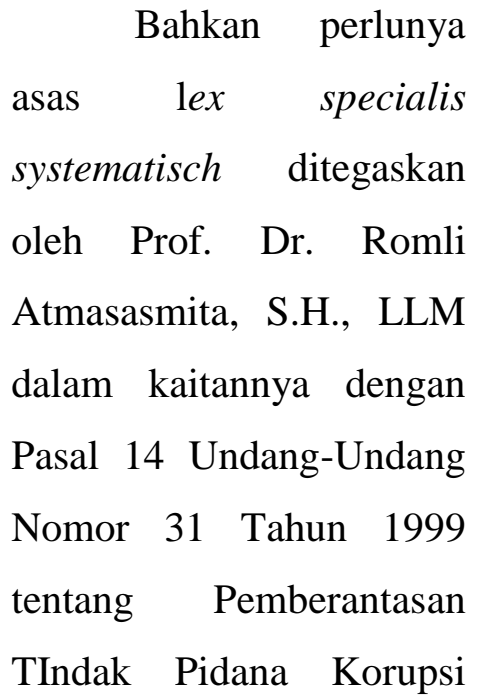

atas suatu perbuatan yang terjadi di dalam aktivitas yang dilindungi suatu undang-undang lain semisal Undang-Undang Perbankan, UndangUndang Perpajakan, Undang-Undang

Kepabeanan, atau UndangUndang Pasar Modal, juga adanya asas lex specialis systematisch dan Pasal 14 Undang-Undang Nomor 31 Tahun 1999 tentang Pemberantasan Tindak Pidana Korupsi menyimpangi asas concursus idealis padsa Pasal 53 ayat (1) KUHP.

\section{Independensi Hakim dalam Memutus Perkara}

Asas kekuasaan kehakiman yang merdeka sebagai salah satu sendi penyelenggaraan Negara Kesatuan Republik Indonesia, tidak dapat 


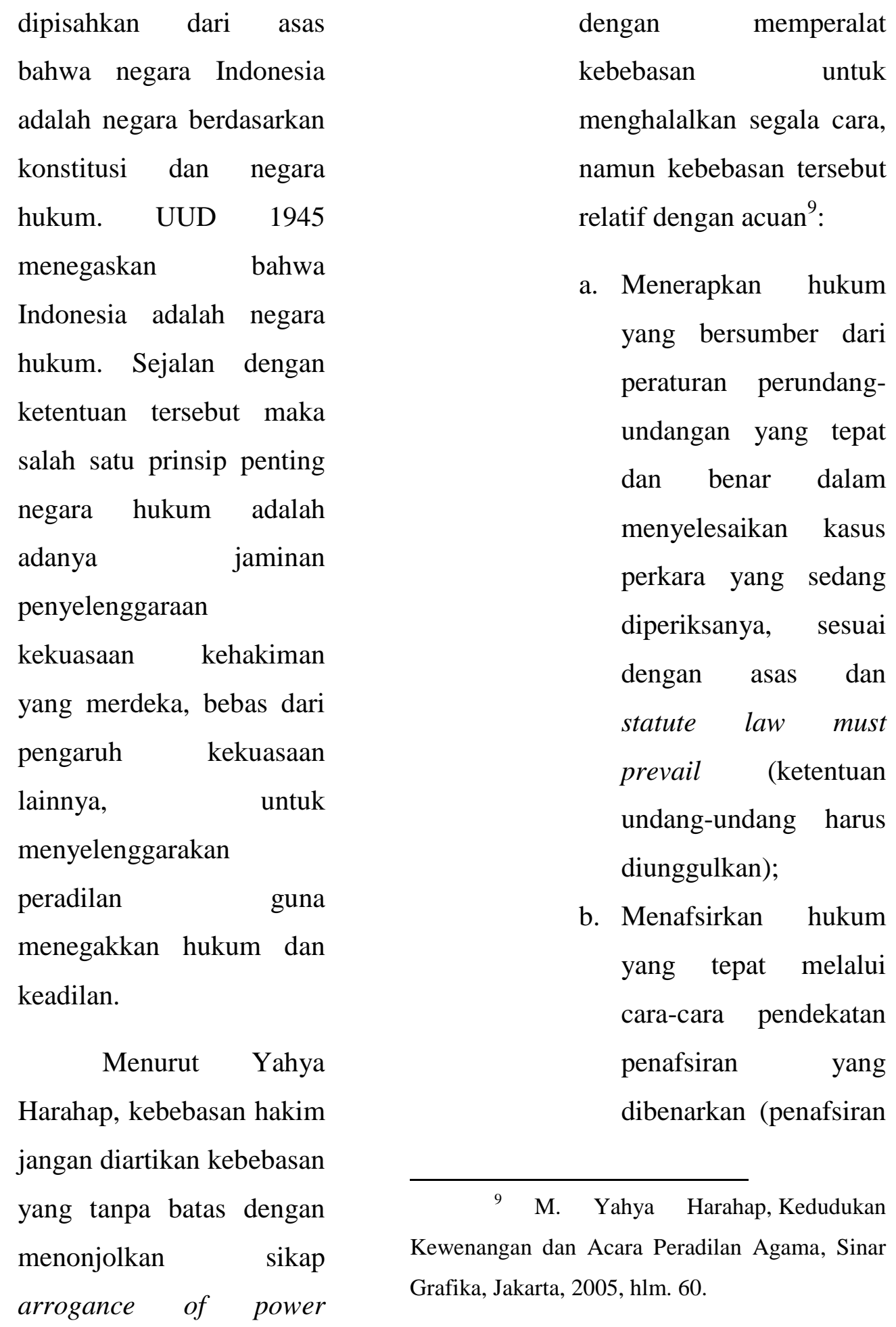


sistematik, sosiologis, bahasa, analogis dan $a$ contrario) atau mengutamakan

keadilan daripada peraturan perundangundangan, apabila ketentuan undangundang tidak potensial melindungi kepentingan umum. Penerapan yang demikian sesuai dengan doktrin equity must prevail (keadilan harus diunggulkan);

c. Kebebasan untuk mencari dan menemukan hukum (rechts vinding), dasardasar dan asas-asas hukum melalui doktrin ilmu hukum, norma hukum tidak tertulis (hukum adat), yurisprudensi maupun melalui pendekatan "realisme" yakni mencari dan menemukan hukum yang terdapat pada nilai ekonomi, moral, agama, kepatutan dan kelaziman.

Dalam batas-batas tersebut di atas jangkauan kebebasan hakim dalam melaksanakan fungsi kekuasaan kehakiman menyelesaikan sengketa perkara yang diperiksa. Bebas menerapkan hukum yang bersmber dari peraturan perundangundangan yang berlaku, asal peraturan dan perundang-undangan yang bersangkutan tepat dan benar untuk diperlakukan terhadap kasus perkara yang diperiksa.

Gagasan

Kedepannya dalam Penerapan Asas Lex 
Specialis Systematisch

Oleh Hakim, jika boleh

dikatakan, selama ini yang terjadi adalah bias arah penegakan hukum dalam pemberantasan korupsi hanya karena praktisi hukum melupakan asasasas umum hukum pidana dalam hubungannya dengan tindak pidana administratif.

Keguncangan

penyelenggara negara dalam menjalankan tugas dan wewenangnya selama ini yang selalu bermuara pada penuntutan tindak pidana korupsi disebabkan karena penegak hukum (jaksa dan hakim) telah mengabaikan pernanan dan fungsi dari asas lex specialis systematisch sebagaimana yang dimuat di dalam Pasal 14 UndangUndang Nomor 31 Tahun
1999 yang telah diubah menjadi Undang-Undang Nomor 20 Tahun 2001. Ketentuan tersebut secara eksplisit memerintahkan penegak hukum untuk mengesampingkan penerapan UndangUndangn Nomor 31 Tahun 1999 terhadap kasus pelanggaran ketentuan pidana pada UndangUndang Adminsitratif (seperti Undang-Undang Perbankan, UndangUndang Perpajakan, Undang-Undang Pasar Modal, dan lain sebaginya) jika pada pelanggaran ketentuan tersebut bukan merupakan tindak pidana korupsi.

Terhadap

perbuatan pemungutan atau pemotongan pajak yang tidak disetorkan ke kas Negara oleh Pegawai 
Negeri Sipil ternyata pada putusan yang berbeda didakwa dan diputus dengan undang-undang yang berbeda. Ada yang didakwa dengan UndangUndang Tindak Pidana Korupsi dan ada juga yang didakwak dengan UndangUndang Ketentuan Umum dan Tata Cara Perpajakan. Begitu juga terhadap perbuatan pelanggaran prinsip kehati-hatian, pada putusan yang berbeda didakwa dan diputus juga dengan Undang-Undang yang berbeda. Ada yang didakwa dengan UndangUndang Tindak Pidana Korupsi dan ada juga yang didakwak dengan UndangUndang Perbankan. Untuk mengatasi permasalahan ini diperlukan suatu pengaturan yang tegas dalam menentukan penerapan undang-undang terhadap suatu perbuatan yang melanggar dua atau lebih ketentuan khusus. Salah satu upaya yang dapat dilakukan untuk mengisi kekosongan hukum ini secara instan dapat dilakukan dengan cara pembuatan Surat Edaran Mahkamah Agung mengenai penerapan asas lex specialis systematisch terhadap penegakan hukum tindak pidana korupsi agar peradilan umum di seluruh Indonesia akan sama bersikap dalam memeriksa dan memutus perkara sejenis, terlebih lagi jika perkara tersebut memenuhi semua unsur pada ketentuan pasal dalam dua atau lebih undang-undang khusus. 
Selain

keseragaman pemahaman

penegak hukum mengenai

asas lex specialis

systematisch, juga

diperlukan penafsiran yang

tepat mengenai kerugian

keuangan negara, karena

tidak semua kerugian

keuangan negara adalah

koruptif. Pasal 14 Undang-

Undang Pemberantasan

Tindak Pidana Korupsi

dapat dikatakan menjadi

tangan penarik tindak

pidana di luar Undang-

Undang Pemberantasan

Tindak Pidana Korupsi

menjadi delik korupsi.

Ketentuan yang

dinyatakan secara tegas

oleh Undang-Undang

bahwa jika pelanggaran

yang dimaksud dinyatakan

sebagai tindak pidana

korupsi, maka Undang-

Undang Pemberantasan
Tindak Pidana Korupsi lah yang menjadi lex specialis systematisch. Dalam hal Undang-undang tidak menyebutkan ketentuan yang dimaksud, maka perhatian yang lebih hatihati dan teliti menjadi sangat diperlukan untuk menerapkan undangundang yang akan diterapkan. Untuk ke depan, formulasi hukum dalam penentuan lex specialis systematisch menjadi urgent.

\section{Kesimpulan}

Berdasarkan pembahasan diatas, dapat disimpulkan:

1. Pada keempat putusan yang diteliti, terdapat perbedaan konstruksi berpikir hakim. Dimana asas lex specialis systematisch tidak diterapkan oleh hakim dalam memeriksa dan memutus perkara. Majelis hakim sependapat dengan 
jaksa penuntut umum yang mendakwakan perbuatan para tersangka sebagai tindak pidana korupsi karena menimbulkan kerugian keuangan negara.

2. Penyebab terjadinya perbedaan putusan hakim dalam menerapkan asas lex specialis systematisch adalah karena: penafsiran hakim terhadap kerugian keuangan negara, independensi hakim dalam memutus perkara, dan disparitas.

\section{DAFTAR PUSTAKA}

\section{A. Buku-Buku}

Amirudin dan Zainal Asikin. 2010. Pengantar Metode Penelitian Hukum, Jakarta: Rajawali Pers.

Hamzah, Andi. 1991. Perkembangan Hukum
Pidana Khusus, Rineka Cipta, Jakarta.

Harahap, M. Yahya. 2005. Kedudukan

Kewenangan dan Acara Peradilan Agama, Jakarta: Sinar Grafika.

Seno Adji, Indriyanto. 2009. Korupsi dan Penegakan Hukum, Jakarta: Diadit Media.

Soekanto, Soerjono dan Sri Mamudji. 2004. Penelitian Hukum Normatif, Jakarta: PT. Raja Grafindo Persada.

Widjajanti, Ermania dan Septa Candra, 2016. Pemikiran Romli Atmasasmita Tentang Pemberantasan Korupsi di Indonesia, Kencana, Jakarta. 


$$
\begin{array}{cr}
\text { Waluyo, } & \text { Bambang. } \\
\text { Penelitian } & \text { Hukum } \\
\text { Dalam } & \text { Praktek, } \\
\text { Jakarta: Sinar } & \text { Garfika. }
\end{array}
$$

\section{B. Undang-Undang}

$$
\begin{array}{lr}
\text { Undang-Undang } & \text { Nomor } 1 \\
\text { tahun } 1946 & \text { tentang } \\
\text { Hukum } & \text { Pidana } \\
\text { (KUHP), } & \text { Tambahan } \\
\text { Lembaran } & \text { Neagara } \\
\text { Republik } & \text { Indonesia } \\
\text { Nomor 3850. }
\end{array}
$$

$\begin{array}{lr}\text { Undang-Undang } & \text { Nomor } 6 \\ \text { Tahun } 1983 & \text { Tentang } \\ \text { Ketentuan } & \text { Umum dan } \\ \text { Tata Cara } & \text { Perpajakan, } \\ \text { Lembaran } & \text { Negara } \\ \text { Republik } & \text { Indonesia } \\ \text { Tahun 1983 Nomor 49, } & \text { Lembaran } \\ \text { Tambahan } & \text { Lemblik } \\ \text { Negara } & \text { Republik } \\ \text { Indonesia } & \text { Nomor } \\ \text { 3262. } & \end{array}$

\begin{tabular}{rr} 
Undang-Undang & \multicolumn{2}{c}{ Republik } \\
Indonesia & Nomor 7 \\
Tahun 1992 & Tentang \\
Perbankan, & Tambahan \\
Lembaran & Negara \\
Republik & Indonesia
\end{tabular}

Nomor 3473.

Undang-Undang Republik

Indonesia Nomor 10

Tahun 1998 Tentang

Perubahan Atas

Undanh-Undang

Nomor 7 Tahun 1992

Tentang Perbankan,

Tambahan Lembaran

Negara Republik

Indonesia Nomor

3790.

Undang-Undang Nomor 31

Tahun 1999 Tentang

Pemberantasan Tindak

Pidana Korupsi,

Lembaran Negara

Republik Indonesia

Tahun 1999 Nomor 
140, Tambahan

Lembaran Negara

Republik Indonesia

Nomor 3874.

$\begin{array}{lr}\text { Undang-Undang } & \text { Nomor } 20 \\ \text { Tahun 2001 } & \text { Tentang } \\ \text { Perubahan } & \text { Atas } \\ \text { Undang-Undang } & \\ \text { Nomor } 31 & \text { Tahun } 1999 \\ \text { Tentang } & \\ \text { Pemberantasan } & \text { Tindak } \\ \text { Pidana } & \text { Korupsi, } \\ \text { Tambahan } & \text { Lembaran } \\ \text { Negara } & \text { Republik } \\ \text { Indonesia } & \text { Nomor } \\ \text { 4150. } & \end{array}$

Undang-Undang Nomor 28

Tahun 2007 Tentang

Perubahan Ketiga Atas

Undang-Undang

Nomor 6 Tahun 1983

Tentang Ketentuan

Umum dan Tata Cara

Perpajakan, Lembaran

Negara Republik
Indonesia Tahun 2007

Nomor 85, Tambahan

Lembaran Negara

Republik Indonesia

Nomor 4740. 